Canadian Journal of Higher Education Revue canadienne d'enseignement supérieur

Volume 47, No. 3, 2017, pages 152 - 169

\title{
Not What I Expected: Early Career Prospects of Doctoral Graduates in Academia
}

\author{
Brittany Etmanski \\ University of Waterloo \\ David Walters \\ University of Guelph \\ David Zarifa \\ Nipissing University
}

\begin{abstract}
Various studies acknowledge the uncertainty many doctoral graduates face when beginning their search for full-time employment within the academic sector. Recent graduates face a job market where the likelihood of obtaining full-time permanent positions in academia is perceived to be declining, and the mobility of graduates within the sector is unclear. Drawing on Statistics Canada's 2013 National Graduates Survey, this paper assesses whether graduates who pursued a doctoral degree to become a full-time professor achieved their goal within three years of graduation. The results suggest that although a large portion of doctoral graduates pursued their degrees to become fulltime professors, relatively few reported obtaining such positions within three years of graduation, regardless of field of study.
\end{abstract}

\section{Résumé}

Plusieurs études attestent de l'incertitude que doivent affronter les titulaires d'un doctorat quand ils entament leurs recherches pour un poste à temps plein dans le secteur universitaire. En effet, les récents diplômés font face à un marché de l'emploi où on perçoit que les chances d'obtenir un poste permanent à temps 
plein dans le secteur académique s'amenuisent, et où la mobilité professionnelle des titulaires d'un doctorat de ce secteur demeure floue. À partir des données de l'Enquête nationale auprès des diplômés 2013 de Statistique Canada, cet article examine la propension des titulaires d'un doctorat souhaitant devenir professeurs à temps plein à réaliser leur objectif sur une période de trois ans après leur collation des grades. Indépendamment du domaine d'étude, les résultats démontrent que, bien qu'une grande proportion de titulaires d'un doctorat aspire à devenir professeurs à temps plein, peu d'entre eux rapportent avoir obtenu de tels postes trois ans après leur remise de diplôme.

The labour market for doctoral graduates has received considerable attention over the last five years. In a previous era, the majority of doctoral graduates sought careers in academia, and many experienced a smooth, linear transition from doctoral and postdoctoral work to a full-time academic position as a professor. In recent years, however, the career prospects and mobility within this sector have become much less certain (Rajagopal, 2002). Despite significant expansion of undergraduate enrolments over the last few decades, increases in the supply of new doctorates have far outpaced the number of positions available for new, full-time professors (Edge \& Munro, 2015; Clark, Trick, \& Van Loon, 2012). New graduates face a highly competitive job market with fewer full-time academic jobs, long bouts of part-time sessional employment, and increased pressures to use their advanced degrees to apply for jobs in other sectors (King, 2005; Manathunga, Pitt, \& Critchley, 2009). At the same time, the average age of graduates is rising, as is their time-to-completion rates (King, 2005; Neumann \& Tan, 2011). As a result, graduates are entering the labour market with fewer years to work full-time, accumulate lifetime earnings, and make significant contributions to their pensions.

The risk of undetermined pathways for recent doctoral graduates is garnering increased attention from researchers, students, and media outlets. Within the academic context, a growing number of current students and recent graduates have begun to express serious concern about the likelihood of obtaining full-time permanent academic employment upon graduation (Harman, 2002; Neumann \& Tan, 2011). Outside the ivory tower, many graduates either are unsure of how to market their doctoral degrees to industry or else view a career pathway outside of academia as a less desirable choice (Gillis, 2013; Pitt \& Cox, 2010; Ryback, 2009).

Existing evidence is mixed as to which sector doctoral graduates are most likely to aspire to upon completion of their doctoral program (Neumann \& Tan, 2011; Pitt \& Cox, 2010). Fullick (2013) suggests universities are simply "producing too many PhDs" (para 6) if the expectation of all graduates is to obtain employment in academia, rather than to market themselves outside of this sector. If most of doctoral graduates still seek academic employment, and the academic sector cannot offer sufficient full-time permanent careers, then doctoral graduates who acquire skills that are less transferable outside of academia may experience the greatest difficulties transitioning into the non-academic labour market. At the same time, waning opportunities for doctoral graduates within the academic sector may prompt credentialing processes in other public or private sectors-potentially leaving new doctorates in positions that do not demand their credentials and with few opportunities to employ their skills. 
Evidence of a gap between expectations of entering the academic sector and actual employment outcomes may point to a mismatch between the supply of recent doctoral graduates and the demands of the workforce-a situation not only of interest to education officials and policymakers who seek to monitor enrolment levels and ensure successful transitions of new graduates into the workforce but also to current graduate students who may be considering a career in academia. However, very little peer-reviewed empirical evidence (particularly in the Canadian context) has examined this phenomenon. This study draws upon a nationally representative survey of the 2010 cohort of Canadian doctoral graduates to examine empirically whether a discrepancy exists between initial career aspirations and employment outcomes three years after graduation.

\section{Literature Review}

\section{Expansion of the Number of Doctorates}

Over the past few decades, the Canadian government has experienced heightened pressure to expand its postsecondary education system in order to create a competitive workforce in the global, knowledge-based economy. Government initiatives to expand doctoral programs, employed in anticipation of the growing number of retirements due to ageing faculty members, were justified on the grounds that the demand for doctoral graduates was expected to grow as new faculty would be needed to service the growth of the postsecondary education system (Maldonado, Wiggers, \& Arnold, 2013). In turn, participation in doctoral studies in Canada steadily increased within recent decades (AUCC, 2011, p. 10; Osborne, Carpenter, Burnett, Rolheiser, \& Korpan, 2014). In fact, the number of PhDs granted in Canada grew by approximately 68\% between 2002 and 2011, while enrolments during the same period increased by more than 70\% (Edge \& Munro, 2015, p. 3). As a result of both this expansion and the increasing number of immigrants with doctoral degrees, over 200,000 people living in Canada held an earned doctorate by the end of the first decade of this century (Edge \& Munro, 2015, p. 3).

Unfortunately, the government-backed growth in graduate student enrolment has not come without consequences for doctoral students and graduates (Hall \& Arnold, 2013; Industry Canada, 2002). Although doctoral graduates have forgone entry into the labour market for extended periods of time, the benefits of obtaining these advanced credentials may not be as clearly defined, especially if they intend to pursue full-time employment within the academic sector. Many graduates must first extend themselves in precarious academic positions (such as postdoctoral or sessional employment) in hopes of becoming more competitive candidates within the academic job market.

\section{Changing Expectations and Outcomes?}

Students pursue doctoral degrees for a variety of reasons, but most commonly to become a university professor (Edge \& Munro, 2015; Osborne et al., 2014). Many are lured into doctoral programs with the expectation that, shortly after graduation, they will be gainfully employed as a full-time professor, with a respectable salary, decent employment benefits, job flexibility and autonomy and, of course, job security. However, as the number of people in Canada with doctoral degrees has continued to rise, there have been growing concerns about whether recent graduates will be able to find employment that is consistent with their aspirations. 
Mobility in the academic sector may be changing. Despite the increasing number of doctoral students and graduates, the number of advertised academic positions have been decreasing (Osborne et al., 2014; Dobbie \& Robinson, 2008; Recotillet, 2007). Of greater significance is that the proportion of contingent faculty has continued to grow within Canada and the United States and now represents the majority of academic faculty members (Dobbie \& Robinson, 2008). Currently, less than one-quarter of Canadian doctoral graduates can expect to obtain full-time academic employment during their time in the labour market (Osborne et al., 2014, p. ii; Sekuler, Crow, \& Annan, 2013).

Given the increasing number of highly qualified graduates and recent reports of their difficulties obtaining full-time academic employment within North America, doctoral degree holders have been expressing a great deal of concern and uncertainty regarding their future employment opportunities and prospects within academia (Harman, 2002; Neumann \& Tan, 2011; Platow, 2012). Using interview data and a social survey conducted in late 2000, Harman (2002) found that many doctoral students do not expect to secure research-intensive (or academic) positions upon graduation. By comparison, a more recent study by Manathunga and Lant (2006) found that most doctoral graduates do end up in the academic or research-driven sectors; what remains unclear is whether they attain full-time jobs as professors.

\section{Differences by Fields of Study?}

To what extent have expectations and employment outcomes varied in terms of the type of doctoral degree pursued and eventually earned? Several European studies suggest that the likelihood of obtaining full-time academic employment can vary greatly according to field of study of the doctoral candidate (Béret, Giret, \& Recotillet, 2002; Enders, 2002; Recotillet, 2007). In some disciplines, there may even be shortages of doctorates due to unmet demands from non-university employers (Clark et al., 2012). In most cases, however, career opportunities outside the academic field may be much more limited. Recotillet (2007), for example, found that social and human science graduates were most drawn to work in the academic sector. This may be due to the smaller number of roles suited to their credentials outside of the academic sector, or that many graduates within these fields may be unaware of the transferable nature of their skills beyond academia. Similarly, Béret et al. (2002) found that graduates in the humanities and social sciences were more likely to obtain initial academic employment. They acknowledge that this finding may be partly explained by the fact that many graduates in the hard sciences choose to pursue work in the private sector. Still, the extent to which those graduates became full-time professors shortly after graduation remains uncertain.

Although the media has expressed concern over the increasing number of doctoral graduates produced in recent years, little empirical evidence within the Canadian context has acknowledged whether they experience hardship obtaining full-time employment as a professor within the first few years of graduation. Identifying the early employment outcomes of recent Canadian graduates helps inform current students about how competitive the academic job market may be upon their graduation and sheds light on whether graduates may be chasing a dream career that is unlikely to materialize in the first three years after graduation. ${ }^{1}$ 
Drawing on Statistics Canada's 2013 National Graduates Survey this study contributes to the existing literature by assessing whether graduates who aspired to become professors when they began their doctoral degrees obtained permanent full-time employment as professors within three years of graduation. More specifically, three related research questions are posed by the current study:

1. To what extent do recent doctoral graduates plan on securing jobs within the academic sector?

2. What proportion of graduates are employed as full-time professors within three years of completing their doctoral work?

3. Do these trends vary by the field study of these doctoral graduates?

\section{Data}

\section{Methods}

To address these questions, this study drew on Statistics Canada's 2013 (class of 2009/2010) National Graduates Survey (NGS). NGS, a nationally representative, crosssectional survey of all postsecondary graduates in Canada, provided the most comprehensive insight into the educational and occupational experiences of recent Canadian graduates. ${ }^{2}$ The survey implements a stratified, random sampling design, and data were collected directly from respondents using computer-assisted telephone interviews from April 2, 2013, to September 1, 2013. ${ }^{3}$ The overall response rate of the survey was $49.1 \%$.

The initial NGS contains information on approximately 28,715 graduates who received a postsecondary credential from a Canadian institution. The analysis for this study was based only on doctoral graduates, as they are the subjects of interest; those with any lower level of qualifications (masters, baccalaureate, college, and trades) were excluded. The final sample for this study included a total of 1,663 respondents who obtained their doctorates in 2009 or 2010.4

A major strength of NGS in examining the workforce outcomes of recent doctoral graduates is Statistics Canada's linking of doctoral graduates' information from the Survey of Earned Doctorates (SED). SED, an annual census of doctoral recipients in Canada, gathered information on how graduates funded their education, their labour market plans after graduation, educational history, and socio-economic characteristics. Combining information from these two surveys allowed us to compare the labour market plans of doctoral graduates at their time of graduation with their actual outcomes three years into the workforce (Statistics Canada, 2009, 2014).

\section{Variables and Procedures}

To assess the extent of a potential gap between academic employment expectations and actual workforce outcomes, the authors used two key dependent variables in their regression analyses. For expectations, the dependent variable in the first series of models asked whether or not the respondents pursued a doctoral degree with the intention of becoming a professor after graduation. ${ }^{5}$ In the second series of models, the dependent variable distinguished between graduates who were employed as full-time professors in 2013 and those who were not. (Respondents were considered to be a professor if they reported their occupation to be "professor," worked full-time in a permanent position, and reported having extended health benefits.) 
To assess the extent to which a potential mismatch between career expectations and outcomes may vary across disciplines, the authors included a variable to capture the doctoral field of study. The initial field of study and occupational classification categories in the NGS are coded by Statistics Canada and are based on the Classification of Instruction (CIP) and National Occupation Classification (NOC). The field of study was recoded into seven meaningful categories:

$\mathrm{O}=$ social sciences and law

$1=$ education

$2=$ humanities and fine arts

$3=$ physical and life sciences

4 = hard sciences (mathematics, computer sciences \& engineering)

$5=$ health, parks and recreation, and fitness

$6=$ other $^{6}$

Table 1. Descriptive Statistics for Variables from the 2013 National Graduates Survey $(n=1663)$

Proportion/Mean

Field of Study

Social sciences

0.19

Humanities and fine arts

0.08

Physical and life sciences

0.22

Hard sciences

0.22

Health and fitness

0.19

Other

0.04

Region of Primary Residence

Atlantic provinces

0.05

Quebec

0.35

Ontario

0.34

Western provinces

0.26

Job Classification

Full-time

0.93

Part-time

0.07

Mother's Education Level

Less than postsecondary

0.40

Postsecondary or higher

0.60

Father's Education Level

Less than postsecondary

0.35

Postsecondary or Higher

0.65

Landed Immigrant in Canada

Yes

0.35

No

0.65 


\begin{tabular}{|c|c|}
\hline & Proportion/Mean \\
\hline \multicolumn{2}{|l|}{ Have Any Dependent Children } \\
\hline Yes & 0.49 \\
\hline No & 0.51 \\
\hline \multicolumn{2}{|l|}{ Marital Status } \\
\hline Married & 0.79 \\
\hline Divorced, widowed, separated & 0.40 \\
\hline Single & 0.17 \\
\hline \multicolumn{2}{|c|}{ Amount Owed on Government Loans at Graduation } \\
\hline$\$ 0$ & 0.66 \\
\hline$\$ 1-10,000$ & 0.10 \\
\hline$>\$ 10,000$ & 0.24 \\
\hline \multicolumn{2}{|c|}{ Identified as a Member of a Visible Minority Group } \\
\hline Yes & 0.29 \\
\hline No & 0.71 \\
\hline \multicolumn{2}{|l|}{ Gender } \\
\hline Male & 0.51 \\
\hline Female & 0.49 \\
\hline Age at Time of Interview & 37.78 \\
\hline \multicolumn{2}{|c|}{ Job Provided Extended Health Benefits } \\
\hline Yes & 0.81 \\
\hline No & 0.19 \\
\hline \multicolumn{2}{|c|}{ Pursued a Doctoral Degree to Become a Professor } \\
\hline No & 0.43 \\
\hline Yes & 0.57 \\
\hline \multicolumn{2}{|l|}{ Occupational Classification } \\
\hline Not a full-time professor & 0.86 \\
\hline Full-time professor & 0.14 \\
\hline \multicolumn{2}{|l|}{ Job Permanent of Not Permanent } \\
\hline Permanent & 0.63 \\
\hline Not permanent & 0.37 \\
\hline
\end{tabular}

As in previous studies predicting employment outcomes with the NGS, the current study also included several key socio-demographic characteristics as control variables (see Walters, 2004; Wright, Walters, \& Zarifa, 2013). These include

- age of respondent at the time of the interview,

- marital status,

- gender,

- visible minority status,

- whether the respondent had dependent children,

- highest level of education attained by each parent of the respondent, and

- the respondent's region of primary residence at the time of the interview. 
The authors also included an additional control for the amount of the respondent's student loans remaining at graduation. ${ }^{7}$ Further details on the variable categories are in Table 1.

\section{Analyses}

The statistical analyses used in this study consisted of both descriptive statistics and two series of binary logistic regressions. The descriptive statistics include the proportions or means of each of the variables included in the analysis. Further, to address the authors' three research questions, they estimated five binary logistic models in a series of stages. Initial models included only their field of study variable, while subsequent models included a number of controls. Models 1 and 2 addressed the first research question by examining the extent of recent doctoral graduates who pursued their doctoral degrees to obtain employment as full-time professors upon graduation. These models also addressed the third research question by examining whether these aspirations vary by the type of degree held by doctoral graduates.

Models 3 to 5 addressed the second research question by predicting the proportion of graduates entering full-time permanent academic positions within three years of graduation. These models also addressed the third research question as they estimated whether the likelihood of obtaining full-time permanent positions in academia within three years of graduation varies by the type of degree and skill sets held by doctoral graduates. Model 3 assesse the effect of field of study on the likelihood of obtaining a full-time permanent position in academia within three years of graduation. Model 4 introduced all control variables to identify any mitigating effects. Finally, Model 5 included the dependent variable from Models 1 and 2 (career aspiration during the doctoral degree).

For Model 2 and Model 5, the coefficients for the field of study variable have been converted to predicted probabilities to provide meaningful comparisons of the results. The predicted probabilities obtained from the regression estimates were calculated holding the control variables constant at typical values.

\section{Descriptive Results}

The results in Table 1 reveal that the number of male and female graduates is nearly even in this study ( $51 \%$ versus $49 \%$ ). The average age of respondents was 38 years old. Most of the doctoral graduates surveyed are from Quebec (35\%) and Ontario (34\%). The majority (65\%) of respondents are not immigrants to Canada, and most of the doctoral graduates in this sample (71\%) did not identify themselves as a visible minority. The majority of graduates reported they were married (79\%), with smaller percentages reporting they were single (17\%) or divorced, widowed, or separated (4\%). The sample was almost evenly split between whether respondents reported any dependent children: the percentage without dependent children (51\%) was almost even with those having dependent children. Most respondents reported that their parents had at least some postsecondary education (60\% of mothers and $65 \%$ of fathers), and most graduates reported having no government debt upon graduation (16\%).

Table 1 also reveals that most of the doctoral graduates are from physical and life sciences (22\%) and hard sciences (22\%), followed closely by the social sciences (19\%) and graduates in health and fitness-related fields (19\%). Approximately, 8\% of respondents 
obtained a doctoral degree in the humanities and fine arts, $6 \%$ received a doctoral degree in an education-related field, and approximately $4 \%$ of the respondents received a doctoral degree in a field classified as "other."

Table 2. Logistic Regression Models: Pursued a Doctoral Degree to Become a Professor $(n=1,663)$

\begin{tabular}{lccccc}
\hline & \multicolumn{2}{c}{ Model 1 } & & \multicolumn{2}{c}{ Model 2 } \\
\cline { 2 - 3 } \cline { 5 - 6 } & $\mathrm{b}$ & $\mathrm{Se}(\mathrm{b})$ & & $\mathrm{b}$ & $\mathrm{Se}(\mathrm{b})$ \\
\hline Constant & $0.565^{* * *}$ & 0.113 & & 1.082 & 0.542
\end{tabular}

Field of Study

Social sciences (ref.)

Education

Humanities and fine arts

Physical and life sciences

Math, computer.science, engineering

Health, parks and recreation, fitness

Other

$\begin{array}{cccc}- & - & - & - \\ -0.340 & 0.288 & -0.398 & 0.306 \\ 1.220^{* * *} & 0.255 & 1.210^{* * *} & 0.261 \\ -0.283 & 0.161 & -0.308 & 0.177 \\ -0.199 & 0.163 & -0.418^{*} & 0.196 \\ -1.142^{* *} & 0.345 & -0.955^{* *} & 0.293 \\ 0.110 & 0.332 & 0.055 & 0.563\end{array}$

Region of Primary Residence

Atlantic provinces (ref.)

Quebec

$\begin{array}{cc}- & - \\ -0.437 & 0.291 \\ -0.661^{*} & 0.272 \\ -0.732^{* *} & 0.273 \\ & \\ - & - \\ 0.216 & 0.201\end{array}$

Ontario

Western provinces

Mother's Education Level

Less than postsecondary

Postsecondary or higher

Father's Education Level

Less than postsecondary

Postsecondary or higher

$\begin{array}{ll}- & - \\ 0.144 & 0.145\end{array}$

Landed Immigrant in Canada

Yes (ref.)

No

$-0.257$

0.244

Dependent Children

Yes (ref.)

No

Marital Status

Married (ref.)

Divorced, widowed, separated

Single

$\begin{array}{cc}- & - \\ -0.016 & 0.289 \\ -0.294 & 0.222\end{array}$




\begin{tabular}{|c|c|c|c|c|}
\hline & \multicolumn{2}{|c|}{ Model 1} & \multicolumn{2}{|c|}{ Model 2} \\
\hline & $\mathrm{b}$ & $\mathrm{Se}(\mathrm{b})$ & $\mathrm{b}$ & $\mathrm{Se}(\mathrm{b})$ \\
\hline \multicolumn{5}{|c|}{$\begin{array}{l}\text { Identified as a Member of a Visible } \\
\text { Minority }\end{array}$} \\
\hline Yes (ref.) & & & - & - \\
\hline No & & & 0.113 & 0.215 \\
\hline \multicolumn{5}{|l|}{ Gender } \\
\hline Male (ref.) & & & - & - \\
\hline Female & & & $0.621^{* * *}$ & 0.161 \\
\hline Age at Time of Interview & & & $0.021^{*}$ & 0.01 \\
\hline \multicolumn{5}{|c|}{$\begin{array}{l}\text { Amount Owed on Government Stu- } \\
\text { dent Loans at Graduation }\end{array}$} \\
\hline \$o (ref.) & & & - & - \\
\hline$\$ 1-10,000$ & & & -0.524 & 0.301 \\
\hline$\$ 10,001+$ & & & -0.126 & 0.195 \\
\hline r-square & 0.0507 & & 0.0880 & \\
\hline $\log \mathrm{L}$ & -2807.3718 & & -2696.9677 & \\
\hline
\end{tabular}

Note: ${ }^{* * *} p<.001,{ }^{* *} p<.01,{ }^{*} p<.05$. Response variable: Whether the respondent pursued a doctoral degree to become a professor: $0=$ No, $1=$ Yes.

Table 3. Predicted Probabilities: Pursued a Doctoral Degree to Become a Professor $(n=$ $1,663)$

\begin{tabular}{lc}
\hline Field of Study & Probability of Doctoral Degree to Become a Professor \\
\hline Social sciences & 0.69 \\
Education & 0.69 \\
Fine arts and humanities & 0.72 \\
Physical and life sciences & 0.68 \\
Hard sciences & 0.68 \\
Health and fitness & 0.66 \\
Other & 0.70 \\
\hline
\end{tabular}

\section{Regression Results}

\section{Pursued a Doctoral Degree to Become a Professor}

In terms of expectations, Table 2 shows the results of the authors' first set of logistic regression models predicting who pursued a doctoral degree to become a professor upon graduation. With respect to the first research question, the results revealed that a large proportion of doctoral students in Canada continued to pursue their doctoral degree in 
hopes of obtaining a full-time academic appointment upon graduation. As per the predicted probabilities for the field of study variable presented in Table 3, the majority pursued their doctoral degree to become a professor, regardless of field of study. Predicted values for those pursuing a doctoral degree to become a professor range from approximately $66 \%$ to $72 \%$, depending on field of study. That is, roughly two-thirds to three-quarters of new doctoral graduates reported that they were completing their degree in hopes of landing an academic position.

These results also speak to the authors' third research question and suggest that trends in pursuing a doctoral degree to become a professor do vary by field of study, but only subtly. As per Table 3, those in the humanities and fine arts were predicted to be more likely to pursue a doctoral degree with the goal of becoming a professor (approximately $72 \%$ ) than those in the social sciences (approximately 70\%). In comparison, those in the hard sciences and health and fitness-related fields were less likely to pursue a doctoral degree to become a professor (approximately 68\% and 66\% respectively) than those in the social sciences. These findings held even when controlling for other variables in the model (as per Model 2) ${ }^{8}$ However, the authors believe it is important to note that the differences according to field of study are slight and are subtler than some of those found by past research (Enders, 2002; Recotillet, 2007). This finding may be due to the Canadian context of the current research, as opposed to the European context of Enders' (2002) and Recotillet's (2007) studies.

Table 4. Logistic Regression Models: Occupational Classification (Full-time Professor or Not) $(n=1,663)$

\begin{tabular}{|c|c|c|c|c|c|c|}
\hline & \multicolumn{2}{|c|}{ Model 3} & \multicolumn{2}{|c|}{ Model 4} & \multicolumn{2}{|c|}{ Model 5} \\
\hline & $\mathrm{b}$ & $\mathrm{Se}(\mathrm{b})$ & $\mathrm{b}$ & $\mathrm{Se}(\mathrm{b})$ & $\mathrm{b}$ & $\operatorname{Se}(b)$ \\
\hline Constant & $-1.196^{* * *}$ & 0.134 & -0.224 & 0.652 & $-1.83^{*}$ & 0.742 \\
\hline \multicolumn{7}{|l|}{ Field of Study } \\
\hline Social sciences (ref.) & - & - & - & - & - & - \\
\hline Education & -0.216 & 0.301 & -0.320 & 0.354 & -0.089 & 0.354 \\
\hline Humanities and fine arts & -0.171 & 0.251 & -0.239 & 0.272 & $-0.590^{*}$ & 0.282 \\
\hline Physical and life sciences & $-1.237^{* * *}$ & 0.252 & $-1.334^{* * *}$ & 0.260 & $-1.370^{* * *}$ & 0.272 \\
\hline $\begin{array}{l}\text { Math, computer science, } \\
\text { engineering }\end{array}$ & $-0.888^{* * *}$ & 0.242 & $-0.896^{* *}$ & 0.271 & $-0.817^{* *}$ & 0.273 \\
\hline $\begin{array}{l}\text { Health, parks \& Recre- } \\
\text { ation, fitness }\end{array}$ & $-0.898^{* *}$ & 0.277 & $-0.745^{*}$ & 0.293 & -0.419 & 0.331 \\
\hline Other & -1.161 & 0.598 & $-1.136^{*}$ & 0.563 & $-1.260^{*}$ & 0.541 \\
\hline \multicolumn{7}{|l|}{ Region of Primary Residence } \\
\hline Atlantic provinces (ref.) & & & - & - & - & - \\
\hline Quebec & & & $-1.254^{* * *}$ & 0.334 & $-1.270^{* * *}$ & 0.353 \\
\hline Ontario & & & $-1.304^{* * *}$ & 0.320 & $-1.230^{* * *}$ & 0.335 \\
\hline Western provinces & & & $-0.971^{* *}$ & 0.324 & $-0.862^{*}$ & 0.337 \\
\hline \multicolumn{7}{|l|}{ Mother's Education Level } \\
\hline Less than Postsecondary & & & - & - & - & - \\
\hline Postsecondary or higher & & & 0.216 & 0.201 & 0.164 & 0.203 \\
\hline
\end{tabular}




\begin{tabular}{|c|c|c|c|c|c|c|}
\hline & \multicolumn{2}{|c|}{ Model 3} & \multicolumn{2}{|c|}{ Model 4} & \multicolumn{2}{|c|}{ Model 5} \\
\hline & $\mathrm{b}$ & $\mathrm{Se}(\mathrm{b})$ & $\mathrm{b}$ & $\mathrm{Se}(\mathrm{b})$ & $\mathrm{b}$ & $\mathrm{Se}(\mathrm{b})$ \\
\hline \multicolumn{7}{|l|}{ Father's Education Level } \\
\hline Less than Postsecondary & & & - & - & - & - \\
\hline Postsecondary or higher & & & -0.013 & 0.203 & 0.025 & 0.204 \\
\hline \multicolumn{7}{|l|}{ Landed Immigrant in } \\
\hline \multicolumn{7}{|l|}{ Canada } \\
\hline Yes (ref.) & & & - & - & - & - \\
\hline No & & & 0.140 & 0.253 & 0.245 & 0.282 \\
\hline \multicolumn{7}{|l|}{ Dependent Children } \\
\hline Yes (ref.) & & & - & - & - & - \\
\hline No & & & -0.172 & 0.193 & -0.015 & 0.202 \\
\hline \multicolumn{7}{|l|}{ Marital Status } \\
\hline Married (ref.) & & & - & - & - & - \\
\hline $\begin{array}{l}\text { Divorced, widowed, or } \\
\text { separated }\end{array}$ & & & 0.263 & 0.391 & 0.310 & 0.397 \\
\hline Single & & & -0.485 & 0.261 & -0.387 & 0.260 \\
\hline \multirow{2}{*}{\multicolumn{7}{|c|}{$\begin{array}{l}\text { Identified as a Member of a } \\
\text { Visible Minority }\end{array}$}} \\
\hline & & & & & & \\
\hline Yes (ref.) & & & - & - & - & - \\
\hline No & & & 0.455 & 0.267 & 0.425 & 0.290 \\
\hline \multicolumn{7}{|l|}{ Gender } \\
\hline Male (ref.) & & & - & - & - & - \\
\hline Female & & & $-0.427^{*}$ & 0.179 & -0.241 & 0.191 \\
\hline Age at Time of Interview & & & 0.002 & 0.012 & -0.007 & 0.013 \\
\hline \multicolumn{7}{|l|}{$\begin{array}{l}\text { Amount Owed on Govern- } \\
\text { ment Student Loans at } \\
\text { Graduation }\end{array}$} \\
\hline \$o (ref.) & & & - & - & - & - \\
\hline$\$ 1-10,000$ & & & $-1.104^{*}$ & 0.43 & -0.997 & 0.402 \\
\hline$\$ 10,001+$ & & & -0.383 & 0.231 & -0.347 & 0.24 \\
\hline \multirow{2}{*}{\multicolumn{7}{|c|}{$\begin{array}{l}\text { Pursued a PhD to Become a } \\
\text { Professor }\end{array}$}} \\
\hline & & & & & & \\
\hline No (ref.) & & & & & - & - \\
\hline Yes & & & & & $2.160^{* * *}$ & 0.256 \\
\hline$r$-square & 0.0336 & & 0.0821 & & 0.1718 & \\
\hline $\log \mathbf{L}$ & -1675.0249 & & -1590.8394 & & $-1435 \cdot 3515$ & \\
\hline
\end{tabular}

Note: ${ }^{* * *} p<.001,{ }^{* *} p<.01,{ }^{*} p<.05$. Response variable: The occupation status of the respondent: $0=$ Not a full-time professor, 1 = Full-time professor.

\section{Occupational Classification (Full-time Professor or Not)}

In terms of actual outcomes, Table 3 shows the results of the authors' second set of logistic regression models predicting the likelihood of being employed as a full-time profes- 
sor. This variable may underestimate the total percentage of doctoral graduates who obtained full-time employment in academia, as the data pertains only to the first three years after graduation. However, it is the authors' opinion that it becomes increasingly difficult for doctoral graduates to obtain full-time academic employment as time passes beyond graduation, though little if any peer-reviewed empirical evidence has examined this phenomenon. Nevertheless, the authors believe the current analysis provides valuable information regarding doctoral graduates' initial employment outcomes in academia.

Table 5. Predicted Probabilities: Occupational Classification (Full-time Professor or Not $)(n=1,663)$

\begin{tabular}{lc}
\hline Model 5 & \\
\hline Field of Study & Probability of Reporting Employment as a Professor \\
Social Sciences & 0.15 \\
Education & 0.15 \\
Fine Arts and Humanities & 0.15 \\
Physical and Life Sciences & 0.12 \\
Hard Sciences (Math, Eng., Etc.) & 0.13 \\
Health and Fitness & 0.14 \\
Other & 0.14 \\
\hline
\end{tabular}

The purpose of the second set of logistic regressions was to examine the likelihood of obtaining a full-time permanent position in academia within three years of graduation, based on factors such as field of study, graduates' initial career aspirations (to become a professor or not), and other mitigating factors. The results for Models 3 to 5 are presented in Tables 4 and 5 . Further, the estimates in Model 5 were used to calculate predicted probabilities for the field of study variable presented in Table 5 .

When answering the second research question, the authors' results indicated that the doctoral students' aspirations to become a professor were unlikely to materialize within the first three years after graduation. In fact, the predicted probabilities (see Table 5) revealed that only a relatively small percentage of graduates were predicted to obtain full-time permanent positions in academia within three years of graduation, regardless of field of study. Predicted values for the probability of obtaining a full-time permanent position as a professor range from approximately $12 \%$ to $15 \%$, depending on field of study. These percentages are considerably lower than those described earlier for students who were seeking to become a professor, suggesting a significant mismatch in expectations and early workforce outcomes.

When addressing the third research question, the probability of obtaining employment as a full-time permanent professor varied by field of study, but once again only subtly. As per Table 5, those in all fields were less likely to report employment as full-time professors than those in the social sciences. Those in the humanities and fine arts (approximately 14.6\%), physical and life sciences (approximately 11.6\%), hard sciences (approximately 11.6\%), health and fitness (approximately 14.1\%), and other (approximately 14.4\%) categories were all less likely to report employment as full-time professors than those in the social sciences 
(approximately 15\%), even when controlling for other variables in the model. ${ }^{9}$ These results echo those of Enders (2002) and Recotillet (2007), though the differences between fields is less distinct than those of the previous studies. (The difference among fields may be due to the differing geographical context of this study versus the earlier studies.)

\section{Discussion and Conclusion}

This study makes a significant contribution to the existing literature by providing a comparison of the aspirations and early employment outcomes of a recent cohort of doctoral graduates in Canada. The authors' findings reveal that a large portion of doctoral graduates pursued their doctoral degree to become a professor; however, a considerably smaller portion of graduates are obtaining such work, regardless of field of study. Since the results indicate a significant portion of doctoral graduates are not obtaining full-time employment that is commensurate with their expectations, they may also suggest that underemployment may be prevalent among graduates of the top tiers of higher education. However, more stringent support for this assertion would involve understanding where such graduates are finding employment along with a close look at the skills they are using on the job. Surprisingly, the results of this study do not suggest that field of study is as important a determinant of whether students pursue a doctoral degree to become a university professor as the authors expected. Nor do the results suggest whether they are likely to obtain a job as a full-time professor three years after graduation.

These findings important for not only for current and future doctoral students but also they are of pressing concern for institutional officials and policy makers who are responsible for keeping a close eye on enrolment expansion and the workforce demands of doctoral graduates in Canada.

This study has a few noteworthy limitations. The NGS, unfortunately, limited the authors from adequately controlling for variables relating to research productivity (quantity or quality of publications) or teaching experience. In addition, the work-related variables in the dataset did not allow the authors to identify if the respondents employed as fulltime professors were engaged in a tenure-track position or a stable contract position, or if their employment was at a university or college. Instead, the authors considered the respondents to be "professors" if they identified their employment as full-time and permanent and if they also received a full set of employment benefits. Nevertheless, the authors expect that most of the respondents they classify as professors are employed tenure-track (or equivalent) positions at universities. Thus, the percentage of doctoral graduates employed as tenured or tenure-track professors three years after graduation is likely lower than the authors have estimated in their models.

Future research in this area would benefit from examining the extent to which doctoral graduates are employed in part-time or sessional teaching positions. Such research would provide a timely contribution to the literature, as the use of precarious work within academic settings has received growing media attention in recent years. It would also help to better understand the extent to which the credentialing process is affecting Canada's most highly educated workers and to assess the extent to which recent doctoral graduates must first extend themselves in postdoctoral or sessional employment in hopes of increasing their competitiveness within the academic market. 
Further, comparative research would also be valuable when identifying changes over time in the career expectations and employment outcomes among doctoral graduates. This would enable researchers to assess whether it has become more difficult for recent doctoral graduates of various fields to obtain work as a full-time professor in comparison with their counterparts in other cohorts. It would also allow researchers to examine the extent to which the expectations of doctoral students change in response to labour market difficulties. Unfortunately, graduates of previous NGS cohorts were surveyed two years after graduation, whereas graduates included in the most recent wave were surveyed three years after graduation, making such comparisons problematic. Hopefully, future NGS will continue to survey graduates three years after graduation from this point forward so that comparisons can be made with the 2013 cohort.

\section{Acknowledgements}

The authors wish to thank Dr. Janice Aurini, as well as the four anonymous reviewers, for comments and suggestions on an earlier draft of this paper. The authors would also like to thank the South-Western Ontario Research Data Centre (SWO-RDC) for access to the data. We acknowledge the support of the Social Sciences and Humanities Research Council of Canada (Grant \#430-2012-0376).

\section{References}

AUCC (Association of Universities and Colleges of Canada). (2011). Trends in higher education: Volume 1-enrolment. Retrieved from Association of Universities and Colleges of Canada: http://www.cais.ca/uploaded/trends-2011-vol1-enrolment-e.pdf

Béret, P., Giret, J. F., \& Recotillet, I. (2003). Trajectories from public sector of research to private sector: An analysis using French data on young PhD graduates. 15th Annual meeting on Socio-Economics, SASE - Society for the advancement of socio-economics, 26-28 juin 2003, Aix-en-Provence, France. (halshs-00006142) Retrieved from Hyper Articles en Ligne: https://hal.archives-ouvertes.fr/halshs-00006142/document

Clark, I., D. Trick, D., \& Van Loon, R. (2012 May 4). Expanding graduate programs and renewing the professoriate: What's the connection? Retrieved from: http://www. academicmatters.ca/2012/05/expanding-graduate-programs-and-renewing-theprofessoriate-whats-the-connection/

Dobbie, D., \& Robinson, I. (2008). Reorganizing higher education in the United States and Canada: The erosion of tenure and the unionization of contingent faculty. Labor Studies Journal, 33(2), 117-140.

Edge, J., \& Munro, D. (2015). Inside and outside the academy: Valuing and preparing PhDs for careers. Retrieved from The Conference Board of Canada: https://uwaterloo. ca/arts-graduate-careers/sites/ca.arts-graduate-careers/files/uploads/files/7564_ inside20and20outside2othe2oacademy_rpt.pdf

Enders, J. (2002). Serving many masters: The $\mathrm{PhD}$ on the labour market, the everlasting need of inequality, and the premature death of Humboldt. Higher Education, $44,493-517$. 
Fullick, M. (2013, April 12). Who will hire all the PhDs? Not Canada's universities. The Globe and Mail. Retrieved from: http://www.theglobeandmail.com/news/national/ education/who-will-hire-all-the-phds-not-canadas-universities/article10976412/

Gillis, C. (2013, June 3). Are Ph.D.s an academic dead zone? Maclean's. Retrieved from: http://www.macleans.ca/society/life/an-academic-dead-zone/

Hall, F., \& Arnold, H. (2013). Intentions for and outcomes following a decade of government investment in graduate education. Toronto, ON: Higher Education Quality Council of Ontario.

Harman, G. (2002). Producing PhD graduates in Australia for the knowledge economy. Higher Education Research \& Development, 21(2), 179-190.

Industry Canada (2002). Achieving excellence: Investing in people, knowledge and opportunities. (Catalogue number C2-596/2001-1E-IN2). Retrieved from Canada's Innovation Strategy: http://publications.gc.ca/collections/Collection/C2-596-2001-1E.pdf

King, D. (2005). Doctoral graduates in Canada: Findings from the survey of earned doctorates, 2004/2005. Retrieved from The Centre of Culture and Education Statistics: http://www.statcan.gc.ca/pub/81-595-m/81-595-m2008065-eng.htm

Maldonado, V., Wiggers, R., \& Arnold, C. (2013). So you want to earn a PhD? The attraction, realities, and outcomes of pursuing a doctorate. (Report No. 15). Retrieved from The Higher Educational Quality Council of Ontario: http://www.heqco.ca/ SiteCollectionDocuments/At\%20Issue\%20Doctoral\%20ENGLISH.pdf

Manathunga, C., \& Lant, P. (2006). How do we ensure good PhD student outcomes? Education for Chemical Engineers, 1(1), 72-81.

Manathunga, C., Pitt, R., \& Critchley, C. (2009). Graduate attribute development and employment outcomes: Tracking PhD graduates. Assessment \& Evaluation in Higher Education, 34(1), 91-103.

Neumann, R., \& Tan, K. (2011). From PhD to initial employment: The doctorate in a knowledge economy. Studies in Higher Education, 36(5), 601-614.

Osborne, B., Carpenter, S., Burnett, M., Rolheiser, C., \& Korpan, C. (2014). Introduction from the special issue editors: Preparing graduate students for a changing world of work. Canadian Journal of Higher Education, 44(3), i-ix.

Pitt, R., \& Cox, M. L. (2010). Gender differences of PhD graduates 5- to-1O-years post-PhD. Queensland: The University of Queensland.

Platow, M. J. (2012). PhD experience and subsequent outcomes: A look at selfperceptions of acquired graduate attributes and supervisor support. Studies in Higher Education, 37(1), 103-118.

Rajagopal, I. (2002). Hidden academics: Contract faculty in Canadian universities. Toronto, ON: University of Toronto Press.

Recotillet, I. (2007). PhD graduates with post-doctoral qualification in the private sector: Does it pay off? Labour, 21(3), 473-502. 
Sekuler, A. B., Crow, B., \& Annan, R. B. (2013). Beyond labs and libraries: Career pathways for doctoral students. Toronto, ON: Higher Education Quality Council of Ontario.

Statistics Canada (2009). Survey of Earned Doctorates (SED). Retrieved from: http:// www23.statcan.gc.ca/imdb/p2SV.pl?Function=getSurvey\&SDDS=3126

Statistics Canada. (2014). National Graduates Survey (NGS). Retrieved from: http:// www23.statcan.gc.ca/imdb/p2SV.pl? Function=getSurvey\&SDDS=5012

Walters, D. (2004). The relationship between postsecondary education and skill: Comparing credentialism with human capital theory. The Journal of Higher Education 34(2), 97-124.

Wright, L., Walters, D., \& Zarifa, D. (2013). Government student loan

default: Differences between graduates of the liberal arts and applied fields in Canadian colleges and universities. Canadian Review of Sociology, 5o(1), 89-115.

\section{Notes}

1 Though beyond the scope of the current analysis, the authors believe that remaining in postdoctoral or sessional positions (or leaving academia) for an extended period (in this case, beyond the three years examined in the 2013 NGS) may make it more difficult to re-enter academia. Therefore, this may be an area of interest for future research.

2 While the NGS is limited to only doctoral graduates from Canadian postsecondary institutions, questions related to employment experiences are not limited to the Canadian labour market.

3 While participation in the survey is voluntary, it is important to note that the sample selection is not voluntary: respondents are randomly selected to represent graduates with similar characteristics. Statistics Canada's data collection consists of a number of followups and callbacks to minimize survey non-response and to maintain a nationally representative sample of new graduates (for further details, see Statistics Canada, 2014).

4 The final sample for the authors' analyses is based only on NGS respondents who received a doctoral degree in 2009/2010. List-wise deletion was used to deal with missing cases.

5 The authors' task in this paper is to compare student expectations with their early workforce outcomes. While self-reported measures may introduce an element of bias that cannot be accounted for in their analyses, the authors' focus necessitates the use of a self-reported measure of expectations, which they eventually compare to their objective employment status measure.

6 This category includes graduates of business administration due to issues relating to sample size.

7 Amount of student loans was categorized as: $0=\$ 0,1=\$ 1-10,000$, and $2=\$ 10,001$ or more. Values 1 and 2 were categorized in this way to ensure the percentages of those belonging in either category were as similar as possible.

8 In terms of the level of statistical significance, as per the coefficients of Models 1 and 2 in Table 2, statistically significant results were obtained for those in the humanities 
and fine arts ( $p<.001$ as per Model 1 and 2), health and fitness-related fields ( $p<.01$ as per Models 1 and 2) and those in the hard sciences ( $p<.05$ as per Model 2).

9 In terms of the level of statistical significance, as per the coefficients of Models 3 to 5 in Tables 3 and 4, statistically significant results were obtained for those in the humanities and fine arts ( $p<.05$ as per Model 5$)$, physical and life sciences $(p<.001$ as per Models 4 and 5 ), hard sciences ( $p<.001$ as per Models 3 through 5 ), health and fitness-related fields ( $p<.01$ as per Models 3 and 4$)$, and "other" categories $(p<.05$ as per Models 4 and 5).

\section{Contact Information}

Brittany Etmanski

Department of Sociology \& Legal Studies

University of Waterloo

betmansk@uwaterloo.ca

Brittany Etmanski is a PhD candidate in the Department of Sociology \& Legal Studies at the University of Waterloo. Her research focuses primarily on the educational and employment outcomes of postsecondary students and graduates. Her SSHRC-funded dissertation research examines the career pathways of recent $\mathrm{PhD}$ graduates.

David Walters is an Associate Professor in the Department of Sociology and Anthropology at the University of Guelph where he teaches undergraduate courses in research methods and graduate courses on general and generalized linear models. His primary area of concentration is quantitative methods and applied statistics, and his substantive areas of applied research include the sociology of education, criminology, and immigration.

David Zarifa is a Canada Research Chair in Life Course Transitions in Northern and Rural Communities and Associate Professor of Sociology at Nipissing University. His previous work has examined inequalities relating to postsecondary access, school-to-work transitions, workforce outcomes, and literacy and skills. He is currently examining higher education access, employment outcomes, and youth migration patterns among Northern and rural residents. 